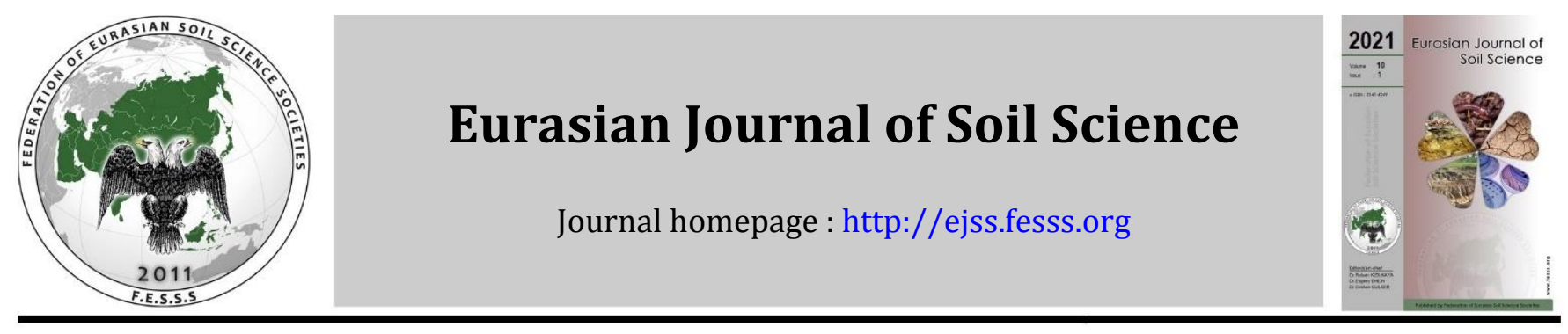

\title{
Short-term effect of rice straw application on soil fertility and rice yield
}

\section{Md. Zulfiker Ali a, Mohammad Saiful Alam a,*, GKM Mustafizur Rahman a, Md. Mizanur Rahman a, Md. Moshiul Islam b, Md. Ziauddin Kamal a, Md. Shahadat Hossain c}

a Department of Soil Science, Bangabandhu Sheikh Mujibur Rahman Agricultural University, Gazipur, Bangladesh

b Department of Agronomy, Bangabandhu Sheikh Mujibur Rahman Agricultural University, Gazipur, Bangladesh

c Department of Soil Science, Sylhet Agricultural University, Sylhet, Bangladesh

\section{Article Info}

Received : 25.03.2019

Accepted : 01.09.2020

Available online : 21.09.2020

\section{Author(s)}

Md.Z. Ali

M.S. Alam *

GKM M. Rahman

Md.M. Rahman

Md.M. Islam

Md.Z. Kamal

Md.S. Hossain

* Corresponding author

\begin{abstract}
The study was conducted at the experimental field of the Department of Soil Science of Bangabandhu Sheikh Mujibur Rahman Agricultural University (BSMRAU), Gazipur, Bangladesh during July to November 2015 in transplanted aman (T. aman) season to evaluate the influence of rice straw application on growth and yield of rice (BINA dhan7) and soil fertility. The experimentation was established following a randomized complete block design (RCBD) using 3 treatments (T1= Inorganic fertilizer dose as per STB, T2= rice straw + inorganic fertilizer as IPNS basis and T3= Farmer's practice). Results of the experiment showed that application of rice straw along with inorganic fertilizers as IPNS basis did not produce any significant $(\mathrm{p}<0.05)$ variation in yield and yield regulating parameters of $\mathrm{T}$. aman rice but ensured higher filled grains panicle-1 (96.68), 1000- grain weight (23.23g), straw (6.97 t/ha) and grain yield (6.32 $\mathrm{t} / \mathrm{ha}$ ) as compared to other treatments. Short term addition of rice straw in soil did not create any significant influence on post harvest soil nutrient status except $\mathrm{K}$ which was found high. Significantly highest $\mathrm{N}$ contents in grain and straw were observed in straw added plots, which further contributed to higher nutrient uptake by grain and straw.
\end{abstract}

Keywords: Rice Straw, soil fertility, rice yield.

(C) 2021 Federation of Eurasian Soil Science Societies. All rights reserved

\section{Introduction}

As an agricultural country, farmers of Bangladesh grow various crops but rice cultivation is very popular throughout the country having the common cropping pattern of Boro rice- Fallow- T.aman rice (BBS, 2008). Declining soil fertility is one of the important limitations for better crop production all over the world including Bangladesh. Higher dependency on synthetic chemical fertilizers and improper nutrient management without replenishment of organic matter for intensive crop cultivation (about 200\%), use of modern HYVs \& hybrids varieties, cultivation of high biomass potential crops, removal of crop residues from crop fields, use of less or no organic fertilizers, lack of crop rotation, nutrient leaching have resulted in a remarkable nutrient mining from Bangladesh soils has lead to deterioration of soil health and fertility and impaired the productivity of soils in Bangladesh (Rijpma and Jahiruddin, 2004; Islam et al., 2008; Rahman, 2013). Crop residues, poultry litter, animal dung and any other natural manure available in farm household could be considered as a good source of organic fertilizer to be applied to soils (Channabasavanna, 2003).

For agricultural sustainability, nutrient recycling from different sources is very important (King, 1990). From various organic materials, it is possible to use the poultry manure as organic material in some parts of

https://doi.org/10.18393/ejss.797847

http://ejss.fesss.org/10.18393/ejss.797847 
Bangladesh due to rapid expansion of poultry farms, while there is still inadequate availability of poultry manure in most part of the country. Moreover, some reports demonstrated the presence of heavy metals in poultry manure; therefore we have to be cautious in using poultry manure. On the other hand, number of cattle is decreasing in our country day by day due to rapid mechanization in agricultural sector. Therefore, availability of cowdung is decreasing day by day and most of the available cowdung is used as fuel. But among the organic materials, the availability of rice straw is comparatively higher all over the country as most of the farmers grow rice in their wetland fields which could easily be incorporated into the soil as a source of plant nutrients. Rice straw contains about 0.5-.8 \%N, 0.16-.27\% $\mathrm{P}_{2} \mathrm{O}_{5}, 1.4-2.0 \% \mathrm{~K}_{2} \mathrm{O}, 0.05-0.1 \% \mathrm{~S}$ and $4-7 \%$ Si (Dobermann and Fairhurst, 2002). Addition of unnecessary crop residues and straw materials to the field ensure the return of considerable amount of nutrients to the soil as well as facilitate to build nutrient reserves for a longer period of time. So it is revealed that rice straw is the best alternative to maintain organic matter status in soil as well as to sustain soil fertility. In view of the present discussion, the experiment was conducted with the aim of evaluating the influence of rice straw addition on yield regulating parameters as well as yield of rice without deteriorating soil fertility status.

\section{Material and Methods}

A study was carried out at the experimental field (Block- 9) of the Department of Soil Science of BSMRAU, Gazipur, Bangladesh from July 2015 to November 2015 to evaluate the performance of rice straw as organic manures on yield regulating parameters as well as and yield of T.aman rice. Nutrient uptake by rice as well as post harvest soil fertility status was also assessed as influenced by rice straw incorporation. The Shallow Red Brown Terrace soil of the experimental field belongs to Salna series and according to USDA classification system, soils of the study site fall under the order Inceptisol having the pH value around 5.8 (FAO, 1988). The experimental area has subtropical humid climate distinguished by intensive rain for the duration of April to September and inadequate rainfall from the period of October to March.

Before starting the field experiment, initial soil samples were collected from a depth of $0-15 \mathrm{~cm}$ from the experimental field. Collected samples were analyzed for $\mathrm{pH}$, organic carbon (OC in \%), total $\mathrm{N}(\%)$, available $\mathrm{P}(\mathrm{mg} / \mathrm{kg})$, exchangeable $\mathrm{K}, \mathrm{Ca}, \mathrm{Mg}(\mathrm{cmol}(+) / \mathrm{kg})$ and available $\mathrm{S}(\mathrm{mg} / \mathrm{kg})$ by the standard methods. The initial soil sample had pH of 5.7, OC $0.72 \%$, total N $0.09 \%$, available P $8.59 \mathrm{mg} / \mathrm{kg}$, exchangeable K 0.14 , Ca $1.4 \mathrm{cmol} \mathrm{(+)/kg,} \mathrm{Mg} 1.6 \mathrm{cmol}(+) / \mathrm{kg}$ and available S $25.93 \mathrm{mg} / \mathrm{kg}$. Post harvest soil samples were also collected from every replicated plot $(0-15 \mathrm{~cm}$ depth) and analyzed for different chemical properties. The field study was established following Randomized Complete Block Design (RCBD) having six replications for each treatment. The experiment had 18 unit plots where the dimension of each individual plot was $5 \mathrm{~m} \times 4 \mathrm{~m}$ $=20 \mathrm{~m}^{2}$. The spacing was $25 \mathrm{~cm} \times 20 \mathrm{~cm}$. Thirty days old seedlings of the rice variety BINA dhan 7 was transplanted in the field during T-aman rice growing season. The Cropping pattern of the field was Aus- $\mathrm{T}$. aman- Boro.

The experiment was comprised of three treatments which are as follows:

$\mathrm{T}_{1}$ : Soil test based (STB) Inorganic fertilizer dose,

$\mathrm{T}_{2}$ : Rice straw + inorganic fertilizer as IPNS basis and

$\mathrm{T}_{3}$ : Farmer's practice.

Rice straw of the previous aus rice was incorporated into the wet soil (15kg straw/ plot) followed by ploughing so that the rice straw mixes well with the soil. Transplanting of the T-aman rice was carried out three weeks after rice straw incorporation. The full dose of triple super phosphate (TSP), muriate of potash (MoP) and gypsum fertilizer were added during the final land preparation, whereas urea fertilizer was applied as 3 equal installments. Firstly, it was applied at 20 days of transplanting (DOT), second installment of urea was applied at 40 DOT (maximum tillering stage) and the final split of the fertilizer was applied at 60 DOT (panicle initiation stage). Necessary amount of urea, TSP, MoP and gypsum as the source of N, P, K and S respectively were calculated using the following equation as mentioned in FRG (2012). $\mathrm{F}_{\mathrm{r}}=\mathrm{U}_{\mathrm{f}}-\mathrm{C}_{\mathrm{i}} / \mathrm{C}_{\mathrm{s}} \times\left(\mathrm{S}_{\mathrm{t}}-\mathrm{L}_{\mathrm{s}}\right)$ Based on this calculation, necessary amount of fertilizers were as follows: T1: N-P-K-S-Zn @ 65-7-28-8-1 kg/ha, T2: N-P-K-S-Zn @ 55-6-25-7-1 kg/ha and T3: N-P-K @ 69-23-38 kg/ha.

Required intercultural operations were carried out during the whole crop growing season as and when required. After harvest, data were recorded for different parameters including plant height $(\mathrm{cm})$, number of tillers per hill, number of panicles per hill, number of grains per panicles, thousand grain weight (g), grain yield ( $\mathrm{t} / \mathrm{ha}$ ) and straw yield (t/ha). Plant samples were analyzed to determine nitrogen, phosphorus and potassium using standard protocols (Jackson, 1973). Statistical analysis of the experimental data was done using the STATISTIX 10 software for windows. For the better understanding of the obtained results, mean differences of the treatments for each parameter were taken from LSD test considering $5 \%$ level of probability (Gomez and Gomez, 1984). 


\section{Results and Discussion}

\section{Yield contributing characters of rice (BINA dhan7) as influenced by rice straw management in combination with inorganic fertilizers \\ Plant height}

Plant height of BINA dhan7 was significantly affected by different treatment combinations (Table 1). Plant height ranged from $101.2 \mathrm{~cm}$ in treatment $\mathrm{T}_{2}$ (Rice straw residues + Inorganic fertilizer as IPNS basis) to $103.42 \mathrm{~cm}$ in treatment $\mathrm{T}_{3}$ (Farmer's practice). The tallest plant was recorded in $\mathrm{T}_{3}$ treatment but it was statistically comparable with $\mathrm{T}_{1}$ treatment (Fertilizer dose as per STB). Nitrogen is the most important plant nutrients responsible for the vegetative growth of the plants. In case of $\mathrm{T}_{3}$ treatment (Farmer's practice) highest plant height was recorded, which might be resulted because of the application of higher amounts of nitrogenous fertilizers in this treatment. Lowest plant height in rice straw + IPNS based NPK treatment might be as a result of the immobilization of nitrogen due to the addition of rice straw having higher $\mathrm{C}: \mathrm{N}$ ratio (Kumar and Goh, 2000).

Table 1. Yield contributing characters of rice (BINA dhan7) as influenced by rice straw management in combination with inorganic fertilizers

\begin{tabular}{lcccccc}
\hline Treatment & $\begin{array}{c}\text { Plant height } \\
(\mathrm{cm})\end{array}$ & $\begin{array}{c}\text { Number of } \\
\text { tillers hill }^{-1}\end{array}$ & $\begin{array}{c}\text { Number of } \\
\text { Panicles hill }\end{array}$ & $\begin{array}{c}\text { Panicle } \\
\text { Length }(\mathrm{cm})\end{array}$ & $\begin{array}{c}\text { Number of filled } \\
\text { grains panicle }^{-1}\end{array}$ & $\begin{array}{c}\text { No. unfilled grains } \\
\text { panicle }^{-1}\end{array}$ \\
\hline T1 & $101.80 \mathrm{ab}$ & 14.81 & 14.24 & 23.86 & 95.66 & 21.18 \\
T2 & $101.20 \mathrm{~b}$ & 14.39 & 13.51 & 23.20 & 96.68 & 17.03 \\
T3 & $103.42 \mathrm{a}$ & 15.53 & 14.96 & 23.76 & 93.81 & 21.63 \\
S.E. \pm ) & 0.69 & 0.53 & 0.63 & 0.39 & 3.53 & 2.03 \\
CV\% & 0.96 & 5.04 & 6.29 & 2.39 & 5.25 & 14.44 \\
\hline
\end{tabular}

In a column figures having similar letter (s) do not differ significantly whereas figures with dissimilar letter (s) differ significantly as per LSD at $5 \%$ level of significant. Legends, CV= Co-efficient of Variation, $\mathrm{T}_{1}$ : Inorganic fertilizer dose as per STB, T2: Rice straw residues + Inorganic fertilizer as IPNS basis, T3: Farmer's practice

\section{Number of effective tillers per hill}

There was no significant effect of rice straw and other fertilizer treatments on the number of effective tillers hill- $^{-1}$ of BINA dhan7 (Table 1). Results of the present study illustrated that number of tillers hill-1 due to different treatments varied from 14.39 to 15.53 . The maximum number of effective tillers hill-1 (15.33) was obtained from the treatment $\mathrm{T}_{3}$ (Farmer's practice) and the minimum number of effective tillers hill-1 $(14.39)$ was recorded in $\mathrm{T}_{2}$ (Rice straw + inorganic fertilizer as IPNS basis) treatment. Our experimental findings are in line with other research result as reported by Surekha et al. (2003) where non- significant influence of rice straw on number of tillers in the first season of residue application was observed. Slow decomposition rate of rice straw in the initial stage of application might led to the lower release of plant nutrients which trigger less nutrient use efficiency and thus effective tiller became lower in rice straw applied plots than other treatments.

\section{Number of panicles per hill}

Panicle number per hill was not significantly influenced by different treatments (Table 1). Experimental results demonstrated maximum number of panicles per hill in the treatment $\mathrm{T}_{3}$ (Farmer's practice) with a value of 14.96. In contrast, the minimum number of panicles per hill was recorded in the treatment $\mathrm{T}_{2}$ (Rice straw + inorganic fertilizer as IPNS basis) having a value of 13.51. Our results corroborate the findings reported by Surekha et al. (2003) who observed non significant influence of rice straw incorporation on number of panicles per hills in the first season of residue application.

\section{Panicle length}

Experimental findings presented in Table 1 show that panicle length of BINA dhan 7 was affected nonsignificantly by different treatment combinations. It is noteworthy that variation of panicle length under different treatments was very close which ranges from $23.86 \mathrm{~cm}$ to $23.20 \mathrm{~cm}$. Considering different treatments, the longer panicle was recorded in treatment $\mathrm{T}_{1}$ (Fertilizer dose as per STB). On the other hand, the shorter panicle length was recorded from the treatment $\mathrm{T}_{2}$ (Rice straw + inorganic fertilizer as IPNS basis) treatment. The longer panicle length in $\mathrm{T}_{1}$ treatment might be attributed due to the balanced fertilization, whereas due to slow decomposition of the added straw in first season cause lower availability of plant nutrients resulting shorter panicle in $\mathrm{T}_{2}$ treatment.

\section{Number of filled grains per panicle}

Filled grains panicle ${ }^{-1}$ was not significantly affected by various treatments (Table 1). Number of filled grains panicle $^{-1}$ regarding various treatments varied between 93.81 and 96.68. Among different treatments, though 
there is no significant differences but the higher filled grains panicle ${ }^{-1}(96.68)$ was recorded in $\mathrm{T}_{2}$ (Rice straw + inorganic fertilizer as IPNS basis) treatment and the lower number was recorded in $\mathrm{T}_{3}$ (Farmer's practice) treatment. Our findings are in accordance with the findings presented by El-Refaee (2012) that reported the maximum number of grains/panicle in plants treated with NPK + rice straw compost and no significant differences were observed from that of recommended NPK fertilizers. Similarly, none of the yield components including number of grains per panicle were affected by the first season of residue incorporation in rice (Surekha et al., 2003).

\section{Number of unfilled grains per panicle}

Findings of the present study illustrated that unfilled grains panicle ${ }^{-1}$ was non-significantly influenced due to the treatments (Table 1). Study results indicated that the number of unfilled grains panicle-1 varied from 17.03 to 21.63 . The higher number of unfilled grains panicle ${ }^{-1}$ was produced by the treatment $\mathrm{T}_{3}$ (Farmer's practice). It is noteworthy that comparatively higher amounts of NPK fertilizers were applied in this treatment as compared to other treatments. This finding clearly demonstrated that grain formation is highly dependent on the applied nutrient status and higher doses of inorganic fertilizers adversely influence the grain formation in rice. Study results further revealed that lower number of unfilled grains were obtained in $\mathrm{T}_{2}$ (Rice straw + inorganic fertilizer as IPNS basis) treatment. Suitable combination of organic and inorganic fertilizers in $\mathrm{T}_{2}$ treatment may trigger the lower number of unfilled grains per panicle.

\section{Thousand grain weight}

The 1000-grain weight of BINA dhan7 was non-significantly affected by various treatments under the present experiment which is shown in Table 2. The 1000-grain weight was very close for different treatments and ranged from 22.47 to 23.30 g. However, there is no significant variation among the treatments but higher thousand grain weight was documented in $\mathrm{T}_{1}$ (Fertilizer dose as per STB) treatment and the lower value was obtained from the $\mathrm{T}_{3}$ (Farmer's practice) treatment. Our findings are well supported by the results of Surekha et al. (2003) and Ranamukhaarachchi and Ratnayake (2006) who demonstrated non-significant influence of rice straw application over inorganic fertilizers alone on thousand grain weight of rice crop.

Table 2. Grain and straw yield of rice (BINA dhan7) as influenced by rice straw management in combination with inorganic fertilizers

\begin{tabular}{lcrc}
\hline \multirow{2}{*}{ Treatment } & Thousand grain wt & \multicolumn{2}{c}{ Yield (t/ha) } \\
\cline { 3 - 4 } & $(\mathrm{g})$ & Straw & 6.05 \\
$\mathrm{~T}_{1}$ & 23.30 & 6.88 & 6.32 \\
$\mathrm{~T}_{2}$ & 23.23 & 6.97 & 6.28 \\
$\mathrm{~T}_{3}$ & 22.47 & 6.88 & 0.42 \\
S.E. $( \pm)$ & 0.34 & 0.35 & 16.67 \\
$\mathrm{CV} \%$ & 2.11 & 12.66 & \\
\hline
\end{tabular}

In a column figures having similar letter (s) do not differ significantly whereas figures with dissimilar letter (s) differ significantly as per LSD at $5 \%$ level of significant. Legends, CV= Co-efficient of Variation, $\mathrm{T}_{1}$ : Inorganic fertilizer dose as per $\mathrm{STB}, \mathrm{T}_{2}$ : Rice straw residues + Inorganic fertilizer as IPNS basis, $\mathrm{T}_{3}$ : Farmer's practice.

\section{Grain yield ( $t / h a)$}

Rice straw management practices did not demonstrate any significant influence on grain yield of BINA dhan7 (Table 2).Grain yield of rice under the present study varied from 6.05 to $6.32 \mathrm{t} \mathrm{ha}^{-1}$. Among the treatments, higher grain yield $\left(6.32 \mathrm{t} \mathrm{ha}^{-1}\right)$ was obtained in the treatment $\mathrm{T}_{2}$ (Rice straw + inorganic fertilizer as IPNS basis). On the other hand, the lower grain yield (6.05 $\left.\mathrm{t} \mathrm{ha}^{-1}\right)$ was obtained in the $\mathrm{T}_{1}$ (Fertilizer dose as per STB) treatment. These findings imply that application of rice straw for a single season could substitute some portion of synthetic inorganic fertilizers which will not affect the grain yield of rice as compared to the recommended inorganic fertilizers. Moreover, application of higher doses of inorganic fertilizers by the farmers (Treatment 3: Farmer's Practice) could easily be reduced through the application of rice straw along with inorganic fertilizers as IPNS basis without affecting the rice grain yield.

Addition of the crop residues along with straw into the soil replenish the nutrients which facilitate to create nutrient reserves in soil for a considerable period of time for sustainable production systems (Tuyen and Tan, 2001). As compared to other crop residues, availability of rice straw is comparatively higher throughout the country which could incorporate into the soil of wetland rice field very easily. Research findings often demonstrated negligible effect on rice grain yield due to the short term incorporation of crop residues, while in the long run it might benefits considerably. Tuyen and Tan (2001) observed that incorporation of rice straw may increase rice yield about $0.4 \mathrm{tha}^{-1}$ per season. Polthanee et al. (2008) and ElRefaee (2012) reported that incorporation of rice straw into soil did not increase rice yield in the immediate 
season, however long term effect of straw addition would increase crop yield. Our results supported the finding reported by Man et al. (2003) who observed that rice grain yield, in treatment of rice straw after decomposition combined with recommended rate of inorganic fertilizer (NPK), was not significantly different from treatment of $100 \%$ recommended rate of inorganic fertilizer application. Verma and Bhagat (1992) demonstrated that straw incorporation produced wheat yield even less than the control treatment during the first two crops. Prasert and Vitaya (1993) reported significant increase of grain yield after 3 years of rice straw incorporation into the soil.

\section{Straw yield ( $\mathrm{t} / \mathrm{ha})$}

Straw yield of rice varied non-significantly due to various fertilizer treatments and rice straw management practices (Table 2). Results displayed in table 3 indicate that the straw yield of BINA dhan 7 varied from 6.88 to $6.97 \mathrm{t} \mathrm{ha}^{-1}$. The higher straw yield of $6.97 \mathrm{t} \mathrm{ha}^{-1}$ was obtained in $\mathrm{T}_{2}$ (Rice straw + inorganic fertilizer as IPNS basis) treatment and the lower straw yield (6.88 $\mathrm{t} \mathrm{ha}^{-1}$ ) was found in $\mathrm{T}_{1}$ (Fertilizer dose as per STB) and $\mathrm{T}_{3}$ (Farmer's practice) treatments. Our findings are in harmony with the research results of Surekha et al. (2003) who described non-significant influence of rice straw application over inorganic fertilizers alone on the yield of rice straw during dry season of 1999 and 2000. Similar findings were also reported by El-Refaee (2012) during 2011 rice growing season in Egypt. Normally it is assumed that application of rice straw along with inorganic fertilizers would increase the grain as well as straw yield of rice over the application of recommendation doses of inorganic fertilizers. But available literature suggests that significant positive influence of rice straw application might be obtained after few years of rice straw application (Prasert and Vitaya, 1993; El-Refaee, 2012). Non significant influence of rice straw application at the initial seasons might be due to the immobilization of $\mathrm{N}$ resulting from incorporation of rice straw containing higher C:N (60-70) ratio, causing nitrogen deficiency to the subsequent crop (Singh et al., 2001).

Table 3. Chemical properties of postharvest soil $(0-15 \mathrm{~cm})$ as influenced by rice straw management in combination with inorganic fertilizers

\begin{tabular}{|c|c|c|c|c|c|c|c|c|}
\hline \multirow{3}{*}{ Treatment } & \multicolumn{8}{|c|}{ Nutrient content in soil } \\
\hline & \multirow{2}{*}{$\mathrm{pH}$} & OC & $\mathrm{N}$ & $\mathrm{K}$ & $\mathrm{Ca}$ & $\mathrm{Mg}$ & $\mathrm{P}$ & $S$ \\
\hline & & \multicolumn{2}{|c|}{$\%$} & \multicolumn{3}{|c|}{$\mathrm{cmol}(+) / \mathrm{kg}$} & \multicolumn{2}{|c|}{$\mathrm{mg} / \mathrm{kg}$} \\
\hline $\mathrm{T}_{1}$ & 5.68 & 0.74 & $0.11 \mathrm{ab}$ & $0.16 \mathrm{ab}$ & 1.57 & 1.68 & 7.61 & 26.18 \\
\hline $\mathrm{T}_{2}$ & 5.63 & 0.76 & $0.10 \mathrm{~b}$ & $0.20 \mathrm{a}$ & 1.62 & 1.63 & 7.29 & 24.28 \\
\hline $\mathrm{T}_{3}$ & 5.68 & 0.74 & $0.12 \mathrm{a}$ & $0.14 b$ & 1.57 & 1.68 & 7.29 & 24.45 \\
\hline S.E. $( \pm)$ & 0.08 & 0.02 & 0.002 & 0.021 & 0.04 & 0.04 & 0.61 & 1.19 \\
\hline$\% \mathrm{CV}$ & 2.02 & 5.12 & 3.30 & 18.34 & 4.17 & 3.47 & 11.69 & 6.74 \\
\hline
\end{tabular}

In a column figures having similar letter (s) do not differ significantly whereas figures with dissimilar letter (s) differ significantly as per LSD at 5\% level of significant. Legends, CV= Co-efficient of Variation, T1: Inorganic fertilizer dose as per STB, T2: Rice straw residues + Inorganic fertilizer as IPNS basis, T3: Farmer's practice.

\section{Nutrient uptake by rice grain}

Nitrogen uptake by grain was significantly affected by various treatments (Figure 1). Results presented in figure 1reveal that the $\mathrm{N}$ uptake by rice grain ranged from 75.41 to $66.20 \mathrm{~kg} \mathrm{ha}^{-1}$. Significantly highest $\mathrm{N}$ uptake (75.41 kg ha-1) by rice grain was estimated in $\mathrm{T}_{2}$ (Rice straw + inorganic fertilizer as IPNS basis) treatment which was statistically identical with $\mathrm{T}_{3}$ (Farmer's practice) treatment having a value of $70.75 \mathrm{~kg}$ $\mathrm{ha}^{-1}$. In contrast, significantly lowest $\mathrm{N}$ uptake $\left(66.20 \mathrm{~kg} \mathrm{ha}^{-1}\right)$ by grain was obtained from the $\mathrm{T}_{1}$ (Fertilizer dose as per STB) treatment. Among the treatments, the highest $\mathrm{N}$ uptake in $\mathrm{T}_{2}$ treatment might be due to higher dry matter production and nutrient concentration following straw incorporation. Kumar and Goh (2000) showed similar findings and proved that application nutrients from both organic and inorganic sources remarkably enhanced $\mathrm{N}$ uptake.

Phosphorus uptake by rice grain also differed significantly with various treatments (Figure 2). Study results demonstrated in Figure 2 indicate that $\mathrm{P}$ uptake ranged from 11.19 to $13.58 \mathrm{~kg} \mathrm{ha}^{-1}$. Significantly highest $\mathrm{P}$ uptake (13.58 kg ha-1) was calculated in $\mathrm{T}_{2}$ (Rice straw + inorganic fertilizer as IPNS basis) treatment which was statistically alike with $\mathrm{T}_{3}$ (Farmer's practice) treatment. Significantly lowest $\mathrm{P}$ uptake $\left(11.19 \mathrm{~kg} \mathrm{ha}^{-1}\right)$ by grain was estimated in $\mathrm{T}_{1}$ (Fertilizer dose as per STB) treatment which was statistically identical with $\mathrm{T}_{3}$ treatment. Study results imply that rice straw addition in soil had profound influence on $\mathrm{P}$ uptake by rice grain. Straw incorporation might have enhanced the availability of both native and applied $P$ throughout the rice growing season under submerged condition which ultimately resulted in the enhanced $\mathrm{P}$ uptake. The increase in available $\mathrm{P}$ due to incorporation of straw might be due to inactivation of $\mathrm{Fe}$ and $\mathrm{Al}$ as well as hydroxyl Al ions, which reduced the fixation of P (Subehia et al., 2005). 


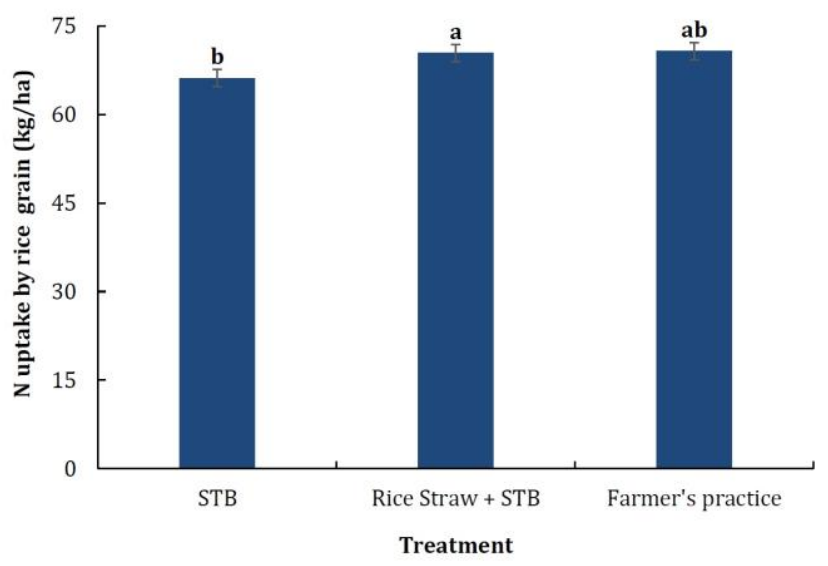

Figure 1. Nitrogen uptake by grain as influenced by rice straw management in combination with inorganic fertilizers

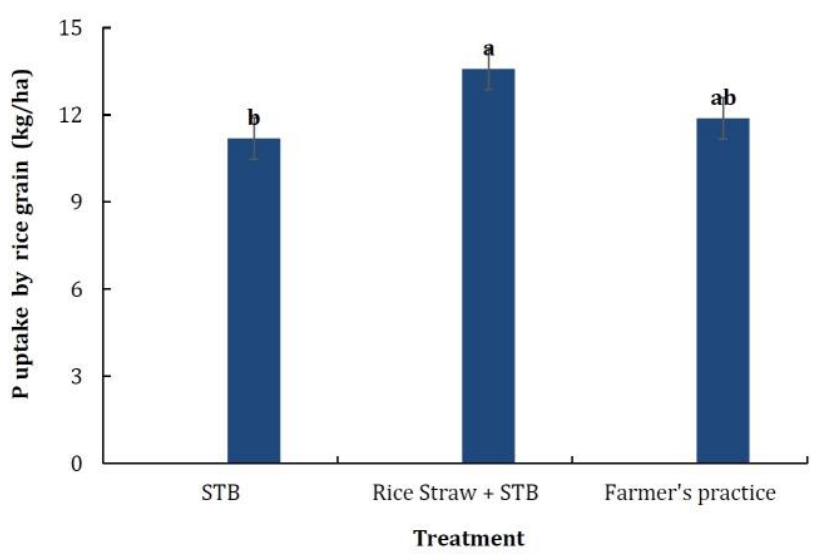

Figure 2. Phosphorus uptake by grain as influenced by rice straw management in combination with inorganic fertilizers

The potassium uptake by grain (BINA dhan7) was also significantly affected by experimental treatments (Figure 3). Potassium uptake under different treatments ranged from a value of 26.40 to $30.43 \mathrm{~kg} \mathrm{ha}^{-1}$. Statistically highest K uptake (30.43 $\mathrm{kg} \mathrm{ha}^{-1}$ ) by rice grain was found in T2 (Rice straw + inorganic fertilizer as IPNS basis) treatment which was statistically identical with treatment T3 (Farmer's practice) having a value of $27.40 \mathrm{~kg} \mathrm{ha}^{-1}$. On the contrary, significantly lowest $\mathrm{K}$ uptake $\left(26.40 \mathrm{~kg} \mathrm{ha}^{-1}\right)$ by grain was recorded in the treatment T1 (Fertilizer dose as per STB) which was statistically identical with T3 treatment. It was observed that straw incorporation significantly increased the nutrient uptake along with $\mathrm{K}$ than control where straw was not incorporated (Kumar and Goh, 2000; Rajkhowa, 2012).

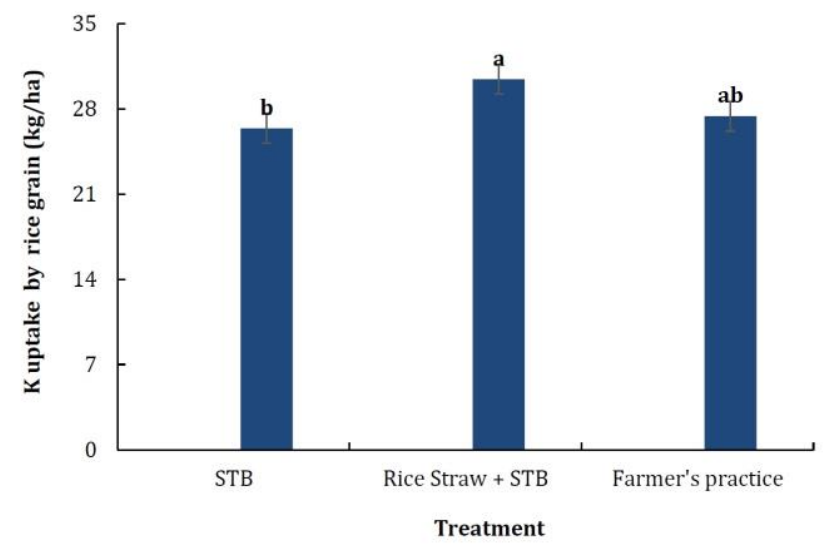

Figure 3. Potassium uptake by grain as influenced by rice straw management in combination with inorganic fertilizers

\section{Post harvest soil properties as influenced by rice straw management in combination with inorganic fertilizers}

\section{Soil pH}

There was no significant influence of rice straw management practices in combination with synthetic fertilizers on the soil pH of post-harvest soil samples (Table 3). However, considering the treatments of the study, higher $\mathrm{pH}$ (5.68) was estimated in $\mathrm{T}_{1}$ (Fertilizer dose as per STB) and $\mathrm{T}_{3}$ (Farmer's practice) treatments and lower $\mathrm{pH}$ in the treatment $\mathrm{T}_{2}$ (Rice straw + inorganic fertilizer as IPNS basis) with a value of 5.63 at $0-15 \mathrm{~cm}$ depth. However, rice straw applied treatment showed slight decrease of soil pH which is in accordance with the research results of Sarwar et al. (2008) who noticed that addition of higher level of compost alone and in combination with inorganic fertilizer in the same level reduced the soil $\mathrm{pH}$. This result is very likely as the rice straw was applied only for a single season which is not enough to influence the soil $\mathrm{pH}$ value.

\section{Soil organic carbon}

No significant differences were observed in the organic carbon status of the postharvest soil samples as influenced by the experimental treatments (Table 3). At 0-15 cm depth, soil organic carbon ranged from 0.74 to $0.76 \%$. Among the different treatments, $\mathrm{T}_{2}$ (Rice straw + inorganic fertilizer as IPNS basis) treatment showed the highest organic carbon content $(0.76 \%)$. Though there is no significant variation among the treatments but rice straw treated plots demonstrated higher organic carbon content as compared to other 
treatments. This is possibly due to the addition of organic matter upon decomposition of rice straw residues in soil. Similar findings were achieved by Saothongnoi et al. (2014) and Pathak et al. (2006) who explained that soil organic carbon increased in rice straw applied treatment in comparison with the control treatment.

\section{Total nitrogen content in soil}

Total nitrogen content of the postharvest soil samples was significantly influenced by the experimental treatments (Table 3). Significantly highest nitrogen (0.12\%) content was illustrated in $\mathrm{T}_{3}$ (Farmer's practice) treatment which was statistically identical with $\mathrm{T}_{1}$ (Fertilizer dose as per STB) treatment. The lowest $\mathrm{N}$ $(0.10 \%)$ was recorded in treatment $\mathrm{T}_{2}$ (Rice straw + inorganic fertilizer as IPNS basis) treatment. This result might be attributed due to lower mineralization of rice straw residues in the first season of application, whereas, comparatively higher doses of application of synthetic inorganic fertilizer in Farmer's practice treatment led to attribute higher total $\mathrm{N}$ in soil.

\section{Available phosphorous in soil}

Available $\mathrm{P}$ content of postharvest soil samples demonstrated no significant differences due to various treatment combinations (Table 3). Available P content varies from $7.29 \mathrm{mg} / \mathrm{kg}$ to $7.61 \mathrm{mg} / \mathrm{kg}$. According to the fertilizer recommendation guide FRG (2012) phosphorus status ranges from low to medium. This is very common phenomena for acidic soil as their might be fixation of $\mathrm{P}$ in acidic soil. Considering the treatments, comparatively higher $\mathrm{P}(7.61 \mathrm{mg} / \mathrm{kg})$ was found in $\mathrm{T}_{1}$ (Fertilizer dose as per STB) treatment and lower available $\mathrm{P}$ both at $\mathrm{T}_{2}$ (Rice straw + inorganic fertilizer as IPNS basis) and $\mathrm{T}_{3}$ (Farmer's practice) treatment with a value of $7.29 \mathrm{mg} / \mathrm{kg}$.

\section{Exchangeable Potassium content in soil}

Experimental results demonstrated a significant variation in exchangeable $\mathrm{K}$ content of the post harvest soil samples collected from a depth of $0-15 \mathrm{~cm}$ (Table 3). Exchangeable K content varied from $0.14-0.20 \mathrm{cmol}$ $(+) / \mathrm{kg}$. The highest $\mathrm{K}(0.20 \mathrm{cmol}(+) / \mathrm{kg})$ content was calculated in $\mathrm{T}_{2}$ (Rice straw + inorganic fertilizer as IPNS basis) treatment but statistically comparable with $\mathrm{T}_{1}$ (Fertilizer dose as per STB) treatment with a value of $0.16(\mathrm{cmol}(+) / \mathrm{kg})$. On the other hand, significantly lowest exchangeable $\mathrm{K}(0.14 \mathrm{cmol}(+) / \mathrm{kg})$ was found in $\mathrm{T}_{3}$ (Farmer's practice) treatment but statistically identical with $\mathrm{T}_{1}$ treatment. Our findings are in line with the results of Gui-mei et al. (2015) and Wen-Wei et al. (2011), where it was showed increased K content in soil due to rice straw addition over control. This might be attributed due to the higher $\mathrm{K}$ content in rice straw which ultimate increase soil K content upon decomposition

\section{Available Sulphur in soil}

Results of the present study reveal that available S content of the postharvest soil sample was influenced non-significantly due to different treatments as shown in the Table 3. Sulphur contents ranged from 24.28 $\mathrm{mg} / \mathrm{kg}$ to $26.18 \mathrm{mg} / \mathrm{kg}$ where the higher sulphur was estimated in treatment $\mathrm{T}_{1}$ (Fertilizer dose as per STB) and the lower value was recorded in $\mathrm{T}_{2}$ (Rice straw + inorganic fertilizer as IPNS basis) treatment.

\section{Other nutrient status in soil}

Post harvest soil samples from a depth of $0-15 \mathrm{~cm}$ were also analyzed to estimate $\mathrm{Ca}$ and $\mathrm{Mg}$ contents and showed no statistical differences among the treatments for both parameters (3). At 0-15 cm soil depth Ca and $\mathrm{Mg}$ contents ranges from 1.57-1.62 mg/kg and $1.63-1.68 \mathrm{mg} / \mathrm{kg}$ respectively. Study results demonstrated that one season addition of rice straw in crop field had no pronounced effect on most of the soil properties however it can reduce the application of synthetic inorganic fertilizers in agriculture and it is assumed that consecutive addition of rice straw for several years would increase the soil fertility as well as crop production.

\section{Conclusion}

Findings of the present experiment revealed that short term effect of rice straw application on yield attributing parameters and yield of rice (BINA dhan 7) was slight however rice straw added treatment produced higher straw and grain yield in comparison with recommended dose as well as farmers practice. Experimental results further reveal that addition of rice straw in one season in the crop field had no pronounced effect on most of the soil properties, except K content was significantly highest. However, straw addition could reduce the application of inorganic fertilizers in agriculture without affecting the crop yields and it is assumed that consecutive addition of rice straw for several years would increase the soil fertility as well as crop production.

\section{Acknowledgment}

The authors are thankful to Bangladesh Krishi Gobeshona Foundation (KGF) for proving the research grant to conduct the present research under the project KGF (TF 27-SF/15). 


\section{References}

BBS, 2008. Bangladesh Bureau of Statistics. Yearbook of Agriculture Statistics of Bangladesh. Ministry of Planning, Government of the People's Republic of Bangladesh. 126p.

Channabasavanna, A.S., 2003. Efficient utilization of poultry manure with inorganic fertilizers in wet land rice. Journal of Maharashtra Agricultural University 27(3): 237-238.

Dobermann, A., Fairhurst, T.H., 2002. Rice straw management. Better Crops International, Special Supplement 16: 7-11.

El-Refaee, I.S., 2012. Effect of application of rice straw compost and NPK fertilizers under some irrigation regimes on grain yield and water productivity of EHR1 hybrid rice cultivar. Journal of Plant Production 3(3): 445-462.

FAO, 1988. Land resources appraisal of Bangladesh for agricultural development report 2: Agro ecological reasons of Bangladesh. Food and Agriculture Organization of the United Nations, Rome, Italy. pp. 212-221.

FRG, 2012. Fertilizer Recommendation Guide, Bangladesh Agricultural Research Council (BARC), Farmgate, Dhaka1215, Bangladesh.274p.

Gomez, K.A., Gomez, A.A., 1984. Statistically procedures for agricultural research. 2nd edition. An international rice research institute book. John Wiley \& Sons. New York, USA. 704p.

Gui-mei, Z., Xiang-yong, L., Min, W.U., 2015. Effect of straw incorporation on soil fertility and yield of rice after tobacco. Fujian Agricultural Science and Technology 1p.

Islam, M.A., Islam, M.R., Sarkar, A.B.S., 2008. Effect of phosphorus on nutrient uptake of japonica and indica rice. Journal of Agriculture and Rural Development 6(1\&2): 7-12.

Jackson, M.L., 1973. Soil Chemical Analysis. Prentice Hall of India Pvt. Ltd., New Delhi. 498p.

King, L.D., 1990. Sustainable agricultural systems. In: Soil nutrient management in the United States. C.A. Edwards, Lal, R., Madden, P., Miller, R.H., House, G. (Eds.). Soil and Water Conservation Society, Ankeny, Iowa, USA. pp.89-106.

Kumar, K., Goh, K.M., 2000. Crop residue management: effects on soil quality, soil nitrogen dynamics, crop yield, and nitrogen recovery. Advances in Agronomy 68: 197-319.

Man, L.H., Khang, V., Watanabe, T., 2003. Improvement of soil fertility by rice straw manure. Omonrice 11: 74-82.

Pathak, H., Singh, R., Bhatia, A., Jain, N., 2006. Recycling of rice straw to improve wheat yield and soil fertility and reduce atmospheric pollution. Paddy Water Environment 4: 111-117.

Polthanee, A., Vidthaya, T., Promsena, K., 2008. Effect of rice straw management and organic fertilizer application on growth and yield of dry direct-seeded rice. Paddy Water Environment 6: 237-241.

Prasert, S., Vitaya, S., 1993. Using organic fertilizer to improve paddy soil in Northeast Thailand. Proceeding of developing rice and cereal crops in Northeast Thailand. Ubonratchatani Rice Research Center, Department of Agriculture, Ministry of Agriculture and Cooperatives. pp.49-71. [in Thai].

Rahman, M.M., 2013. Nutrient-use and carbon-sequestration efficiencies in soils from different organic wastes in rice and tomato cultivation. Communications in Soil Science and Plant Analysis 44(9): 1457-1471.

Rajkhowa, D.J., 2012. Effect of Rice straw management practices on yield of kharif rice and soil fertility under rice-rice cropping system. Journal of the Indian Society of Soil Science 60(3): 208-212.

Ranamukhaarachchi, S.L., Ratnayake, W.M., 2006. The effect of straw, stubble and potassium on grain yield of rice in rice-rice cropping systems in the mid-country wet zone of Sri Lanka. ScienceAsia 32: 151-158.

Rijpma, J., Jahiruddin, M., 2004. National strategy and plan for use of soil nutrient balance in Bangladesh. Final Report of Assignment, SFFP-DANIDA. Journal of Bangladesh Agricultural University 9(1): 37-42.

Saothongnoi, V., Amkha, S., Inubushi, K., Smakgahn, K., 2014. Effect of rice straw incorporation on soil properties and rice yield. Thai Journal of Agricultural Science 47(1): 7-12.

Sarwar, G., Hussain, N., Schmeisky, H., Suhammad, S., Ibrahim, M., Ahmad, S., 2008. Efficiency of various organic residues for enhancing rice-wheat production under normal soil conditions. Pakistan Journal of Botany 40(5): 2107-2113.

Singh, B., Bronson, K.F., Singh, Y., Khera, T.S., Pasuquin, E., 2001. Nitrogen-15 balance and use efficiency as affected by rice residue management in a rice wheat system in Northwest India. Nutrient Cycling in Agroecosystems 59: 227237.

Subehia, S.K., Sudhir, V., Sharma, S.P., 2005. Effect of long-term use of chemical fertilizers with or without organics on forms of soil acidity, phosphorus adsorption and crop yields in an acid soil. Journal of the Indian Society of Soil Science 53(3): 308-314.

Surekha, K., Kumari, A.P.P., Reddy, M.N., Satyanarayana, K., Stacruz, P.C., 2003. Crop residue management to sustain soil fertility and irrigated rice yields. Nutrient Cycling in Agroecosystems 67: 145-154.

Tuyen, T.Q., Tan, P.S., 2001. Effects of straw management, tillage practices on soil fertility and grain yield of rice. Omonrice 9: 74-78.

Verma, T.S., Bhagat, R.M., 1992. Impact of rice straw management practices on yield, nitrogen uptake and soil properties in a wheat-rice rotation in northern India. Fertilizer Research 33: 97-106.

Wen-Wei, Z., Xiao-Jiang, S., Li-Hong, Z., Yue-Cai, S., 2011. Effects of rice straw backed to soil in double rice cropping production. Crop Research 3p. 